\title{
PHOTOSYNTHESIS RATE, CHLOROPHYLL CONTENT AND INITIAL DEVELOPMENT OF PHYSIC NUT WITHOUT MICRONUTRIENT FERTILIZATION ${ }^{(1)}$
}

\author{
Elcio Ferreira dos Santos ${ }^{(2)}$, Bruno José Zanchim ${ }^{(2)}$, Aline Grella de Campos ${ }^{(2)}$, Raphael \\ Florencio Garrone ${ }^{(2)}$ \& José Lavres Junior ${ }^{(3)}$
}

\begin{abstract}
SUMMARY
Few studies in Brazil have addressed the need for micronutrients of physic nut focusing on physiological responses, especially in terms of photosynthesis. The objective of this study was to evaluate the effects of omission of boron (B), copper $(\mathrm{Cu})$, iron ( $\mathrm{Fe})$, manganese $(\mathrm{Mn})$ and zinc $(\mathrm{Zn})$ on Jatropha curcas $\mathrm{L}$.. The experimental design was a randomized block with four replications. The treatments were complete solution (control) and solution without $\mathrm{B}, \mathrm{Cu}, \mathrm{Fe}, \mathrm{Mn}$, and $\mathrm{Zn}$. We evaluated the chlorophyll content (SPAD units), photosynthetic rate, dry matter production and accumulation of micronutrients in plants, resulting from different treatments. The first signs of deficiency were observed for $\mathrm{Fe}$ and B, followed by $\mathrm{Mn}$ and $\mathrm{Zn}$, while no symptoms were observed for $\mathrm{Cu}$ deficiency. The micronutrient omission reduced the dry matter yield, chlorophyll content and photosynthetic rate of the plants differently for each omitted nutrient. It was, however, the omission of Fe that most affected the development of this species in all parameters evaluated. The treatments negatively affected the chlorophyll content, evaluated in SPAD units, and the photosynthetic rate, except for the omission of $B$. However this result was probably due to the concentration effect, since there was a significant reduction in the dry matter production of $B$ deficient plants.
\end{abstract}

Index terms: Jatropha curcas L., nutritional status, dry matter, IRGA, SPAD.

\footnotetext{
(1) Received for publication in November 22, 2012 and approved in June 7, 2013.

(2) Master student, Center for Nuclear Energy in Agriculture - CENA, University of São Paulo. Av. Centenário, 303. Caixa Postal 96. CEP 13416-000 Piracicaba (SP), Brazil. E-mail: elciosantos@cena.usp.br; bzanchim@cena.usp.br; alineg.campos@yahoo.com.br; rfgarrone@yahoo.com.br

(3) Professor, Plant Mineral Nutrition Laboratory, CENA. E-mail: jlavres@usp.br
} 


\title{
RESUMO: TAXA FOTOSSINTÉTICA, TEOR DE CLOROFILA E DESENVOLVIMENTO INICIAL DO PINHÃO-MANSO CULTIVADO COM OMISSÃO DE MICRONUTRIENTES
}

\begin{abstract}
São poucos os estudos brasileiros que contemplam a avaliação nutricional de micronutrientes em pinhão-manso, enfocando respostas fisiológicas, especialmente em termos de fotossintese. Objetivou-se com este trabalho avaliar os efeitos das omissões de boro (B), cobre ( $\mathrm{Cu}$ ), ferro $(\mathrm{Fe})$, manganês $(\mathrm{Mn})$ e de zinco $(\mathrm{Zn})$, nas respostas fisiológicas do Jatropha curcas L.. O delineamento experimental foi em blocos ao acaso com quatro repetições. Os tratamentos das omissões de micronutrientes foram: solução completa (controle) e omissão individual de $\mathrm{B}, \mathrm{Cu}, \mathrm{Fe}, \mathrm{Mn}$, e de $\mathrm{Zn}$. Foram avaliados o teor de clorofila, em unidades $S P A D$, a taxa fotossintética, a produção de matéria seca e os acúmulos dos micronutrientes nas plantas, em razão dos tratamentos. As primeiras manifestações de deficiência foram observadas para o Fe e B, seguidas das de Mn e Zn; contudo, não foram observados sintomas de carência de Cu. A omissão de micronutrientes reduziu a produção de matéria seca, os teores de clorofila e a taxa fotossintética do pinhão-manso, de forma diferente para cada omissão. Porém, a omissão de Fe foi a que mais limitou o desenvolvimento dessa espécie em todos os parâmetros avaliados. Os tratamentos influenciaram negativamente os teores de clorofila, avaliados em unidades $S P A D$, e a taxa fotossintética, exceto para a omissão de B. Entretanto, esse resultado deveu-se, provavelmente, pelo efeito de concentração, visto que houve redução significativa na produção de matéria seca das plantas deficientes em B.
\end{abstract}

Termos de indexação: Jatropha curcas L., diagnose foliar, matéria seca, IRGA, SPAD.

\section{INTRODUCTION}

The high price of crude oil and increasing environmental concerns are prompting greater interest in fuels from renewable sources, such as biodiesel (Openshaw, 2000). Physic nut (Jatropha curcas L.) has a good potential as a raw material for producing this biofuel because of the intrinsic characteristics of the fruits and the ability of this plant to grow in areas unsuitable for other crops (Behera et al., 2010; Parawira, 2010). These fruits contain about $28 \%$ oil per dry mass, and the plants can produce up to $6,000 \mathrm{~kg} \mathrm{ha}^{-1}$ of seeds, from which approximately $2000 \mathrm{~kg} \mathrm{ha}^{-1}$ of oil can be obtained, making this species potentially very profitable as a commercial crop (Saturnino et al., 2005; Dias et al., 2007; Laviola \& Dias, 2008).

In Brazil, the majority of studies on physic nut (shrub or small tree) have evaluated the effect of macronutrients (Lima et al., 2011; Souza et al., 2011; Balota et al., 2012), and only a few addressed the adequate levels of micronutrients (Chaves et al., 2010). Besides, the published studies evaluated the nutritional state only by leaf diagnosis and visual observation (Silva et al., 2009; Maia et al., 2011). The physiological responses, particularly the photosynthesis process, should therefore be investigated under conditions of nutritional stress. Studies of the physiological behavior of this species have so far only considered environmental factors of abiotic stress, such as temperature, water deficit and soil salinity (Silva et al., 2010, 2011). Hence, there is a need to investigate the effects of micronutrients on physic nut quality and yield, focusing on physiological responses, especially the photosynthesis rate and chlorophyll content.

Micronutrients are involved in practically all biochemical and physiological functions, such as energy metabolism, primary and secondary metabolism, regulation of protein biosynthesis genes and various processes of cell signaling and transduction (Mochida \& Shinozaki, 2011). Advances in analytic techniques have improved the knowledge of the nutritional demands of various plant species, shedding more light on the function of micronutrients in plant metabolism, notably the importance of these elements in photosynthesis (Marschner, 1995).

The photosynthesis process is influenced by micronutrients through various modes of action. Boron participates in the carbohydrate metabolism, directly influencing plant development and indirectly affecting the photosynthetic efficiency (Cakmak \& Römheld, 1997). Iron and manganese are involved in the fixation of carbon by activation and constitution of enzymes (Malavolta et al., 1997). In turn, copper participates in the electron transport flow, uniting the two photochemical systems, and zinc acts as an activator of various photosynthetic enzymes of the oxidase class.

Our hypothesis in this study was that the omission of $\mathrm{B}, \mathrm{Cu}, \mathrm{Fe}, \mathrm{Mn}$, and $\mathrm{Zn}$ would cause different responses in physic nut, promoting changes in the dry matter production, in the indirect determination of chlorophyll content (in SPAD units) and the photosynthesis rate, besides the accumulation of these micronutrients in the plants due to the treatments. Therefore, we assessed the effects of absence of $\mathrm{B}, \mathrm{Cu}, \mathrm{Fe}, \mathrm{Mn}$, and $\mathrm{Zn}$ on the physiological responses of Jatropha curcas L.. 


\section{MATERIAL AND METHODS}

\section{Description of the area and experimental design}

The experiment was carried out in a greenhouse of the Center for Nuclear Energy in Agriculture of the University of São Paulo (USP), in Piracicaba, São Paulo State, in the summer and fall of 2010. The experimental design was randomized blocks with four replications. The micronutrient deficiencies were studied in the treatments: complete solution (control) and solution with individual omission of $\mathrm{B}, \mathrm{Cu}, \mathrm{Fe}$, $\mathrm{Mn}$, and $\mathrm{Zn}$. In all treatments, a ratio of 70:30\% between $\mathrm{N}-\mathrm{NO}_{3}{ }^{-}$and $\mathrm{N}-\mathrm{NH}_{4}{ }^{+}$was maintained (Marschner, 1995).

The complete nutrient solution (Lange et al., 2005; Lavres Junior et al., 2005) had the following composition: $6.0 \mathrm{~mL}$ of $\mathrm{KNO}_{3} 1 \mathrm{~mol} \mathrm{~L}^{-1} ; 4.0 \mathrm{~mL}$ of $\mathrm{Ca}\left(\mathrm{NO}_{3}\right) 4 \mathrm{H}_{2} \mathrm{O} 1 \mathrm{~mol} \mathrm{~L}^{-1} ; 2.0 \mathrm{~mL}$ of $\mathrm{NH}_{4} \mathrm{H}_{2} \mathrm{PO}_{4}$ $1 \mathrm{~mol} \mathrm{~L}^{-1} ; 1.0 \mathrm{~mL}$ of $\mathrm{MgSO}_{4} .7 \mathrm{H}_{2} \mathrm{O} 1 \mathrm{~mol} \mathrm{~L}-1 ; 1.0 \mathrm{~mL}$ of Fe-EDTA $0.02 \mathrm{~mol} \mathrm{~L}^{-1}$; $1.0 \mathrm{~mL}$ of KCl $0.05 \mathrm{~mol} \mathrm{~L}^{-1}$; $2.0 \mathrm{~mL}$ of $\mathrm{H}_{3} \mathrm{BO}_{3} 12.5 \mathrm{mmol} \mathrm{L}^{-1} ; 2.0 \mathrm{~mL}$ of $\mathrm{MnSO}_{4} \cdot \mathrm{H}_{2} \mathrm{O} 1 \mathrm{mmol} \mathrm{L}-1 ; 2.0 \mathrm{~mL}$ of $\mathrm{ZnSO}_{4} \cdot 7 \mathrm{H}_{2} \mathrm{O}$ $1 \mathrm{mmol} \mathrm{L}-1 ; 2.0 \mathrm{~mL}$ of $\mathrm{CuSO}_{4} .5 \mathrm{H}_{2} \mathrm{O} 0.25 \mathrm{mmol} \mathrm{L}^{-1}$; and 1.0 of $\mathrm{mL} \mathrm{H}_{2} \mathrm{MoO}_{4}\left(85 \% \mathrm{MoO}_{3}\right) 0.5 \mathrm{mmol} \mathrm{L}^{-1}$. In the solutions in absence of $\mathrm{B}, \mathrm{Cu}, \mathrm{Mn}$ and $\mathrm{Zn}$, the concentrations were identical, except for the respective omitted nutrient.

\section{Installation and development of the experiment}

The seeds were placed on shallow trays to germinate on vermiculite, moistened with a solution of calcium sulfate $\left(\mathrm{CaSO}_{4} 10^{-4} \mathrm{~mol} \mathrm{~L}^{-1}\right)$. When the plantlets reached a height of about $5 \mathrm{~cm}$, they were transferred to larger plastic trays with a volume of $40 \mathrm{~L}$ containing a nutrient solution (Epstein \& Bloom, 2006), modified and diluted to $20 \%$ of the usual concentration. After one week in this modified solution, the plants were transferred to 2.5 -L plastic pots, containing the particular nutrient solution $(2.0 \mathrm{~L})$ to initiate the treatments. The plants were fixed at the base of the stem (root collar) with plastic foam and constantly aerated.

The solution $\mathrm{pH}$ was adjusted whenever necessary to $5.5 \pm 0.5$, by addition of $\mathrm{HCl}\left(0.1 \mathrm{~mol} \mathrm{~L}^{-1}\right)$ and $\mathrm{NaOH}$ $\left(0.1 \mathrm{~mol} \mathrm{~L}^{-1}\right)$. The nutrient solutions were renewed approximately fortnightly, an interval that was extended or shortened according to the $\mathrm{pH}$ and electrical conductivity values (data not shown) and plant development (Beckmann-Calvacante et al., 2010). The volume was completed daily as necessary with deionized water.

\section{Analyses of the chlorophyll content and photosynthesis rate}

The chlorophyll content and photosynthesis rate of the middle lobe of the third and fourth recently expanded leaves were measured (Lavres Junior et al., 2005). The chlorophyll content, expressed in SPAD units, was determined indirectly with a SPAD-502 chlorophyll meter (Minolta ${ }^{\circledR}$ Camera Co., 1989) each week until the end of the experiment (105 days after initiating the treatments). The photosynthesis rate was measured at 105 days after initialing the experiment in the morning, between 9:00 and 11:00 a.m., with an LI 6400 portable infrared gas analyzer (IRGA, Li-Cor ${ }^{\circledR}$, Inc., Lincoln, NE, USA). The $\mathrm{CO}_{2}$ supply was approximately $400 \mathrm{\mu mol} \mathrm{mol}^{-1}$ and the light intensity $1,200 \mu \mathrm{mol} \mathrm{m} \mathrm{m}^{-2} \mathrm{~s}^{-1}$, at a leaf temperature between 20 and $25^{\circ} \mathrm{C}$ (Reis et al., 2009).

\section{Dry matter production and chemical analysis of the plant tissues}

At the end of the experiment (105 days after initiating the treatments), the plants were harvested and separated into leaves (recently expanded, opening and mature), stems and roots. The material was placed in labeled paper bags and dried in a heating chamber at $65{ }^{\circ} \mathrm{C}$ for $72 \mathrm{~h}$. Then the material of each bag was weighed and ground in a Willey mill (with $1.00-\mathrm{mm}$ mesh screen) for chemical analyses of the tissues, according to the method described by Malavolta et al. (1997). The amounts of accumulated $\mathrm{B}, \mathrm{Cu}, \mathrm{Fe}, \mathrm{Mn}$, and $\mathrm{Zn}$ were calculated as the product of the concentration of the element accumulated in the different plant parts by the dry matter production.

\section{Statistical analysis}

The results were analyzed statistically with the SAS program (SAS Institute, 2000). The data were subjected to analysis of variance (ANOVA) by the F-test $(p \leq 0.05)$ and the means of the treatments were compared by the Tukey test $(p \leq 0.05)$, except for the SPAD values in function of the evaluation day. In case of a significant interaction between a SPAD value and the evaluation day, the effect of the treatment was determined by regression analysis. The models were chosen based on the significance of the regression coefficients by the Ftest $(\mathrm{p} \leq 0.05)$ and by the coefficient of determination.

\section{RESULTS AND DISCUSSION}

The first visual symptoms of micronutrient deficiency appeared in the plants deprived of $\mathrm{Fe}$ and B, 25 days after initiating the treatments, followed by signs of $\mathrm{Mn}$ deficiency after 37 days and of $\mathrm{Zn}$ deficiency after 67 days. No visual signs of $\mathrm{Cu}$ deficiency were observed in the experimental period. Lange et al. (2005) found no symptoms of Cu deficiency in castor bean plants either, concluding that the absence of visual symptoms was probably due to the initial accumulation when the young plants were maintained in the diluted complete solution for a period of 23 days, and also by the possible reuse of the $\mathrm{Cu}$ contained in the seeds. Furthermore, this finding 
might also be explained by a possible Cu-use efficiency of plants of the family Euphorbiaceae under low $\mathrm{Cu}$ availability.

The plants grown in the complete treatment produced more root, stem and leaf dry mass than the other treatments (Figure 1). The omission of Fe, B, Mn, $\mathrm{Zn}$ and $\mathrm{Cu}$ reduced the dry matter production of the aerial part (leaves + stems) by $77,58,41,31$ and $26 \%$, respectively, in relation to the complete treatment. For the roots, the omission of $\mathrm{Fe}, \mathrm{Cu}, \mathrm{B}, \mathrm{Mn}$ and $\mathrm{Zn}$ caused reductions of $67,52,51,32$ and $30 \%$, respectively, in relation to the complete treatment.

In other Euphorbiaceae such as castor bean, $\mathrm{Fe}$ deprivation was found to be more limiting to dry matter production (Lange et al., 2005). Iron is closely related to the production of dry mass, because plants with $\mathrm{Fe}$ deficiency present low respiratory activity due to the impairment in the terminal oxidations that occurs in the mitochondria. Iron also participates in the formation of various enzymes involved in the metabolism of $\mathrm{N}$ and $\mathrm{S}$, such as nitrate reductase and sulfite reductase, as well as being a constituent of ferredoxins which are iron-sulfur proteins that mediate electron transfer in a range of metabolic reactions (Epstein \& Bloom, 2006).

The accumulations of $\mathrm{B}, \mathrm{Cu}, \mathrm{Fe}, \mathrm{Mn}$, and $\mathrm{Zn}$ in various parts of the physic nut plants in function of the treatments are shown in table 1 . The total accumulation of these elements in the plants grown in complete solution decreased in the following order: $\mathrm{Fe}>\mathrm{Zn}>\mathrm{Mn}>\mathrm{B}>\mathrm{Cu}$. Compared to the control (complete) treatment, the reductions in micronutrient accumulation in the plant parts varied according to the omitted nutrient (Table 1). A similar result was reported by Lavres Junior et al., (2012) analyzing the same parts of the commercial castor bean hybrid Íris.

Examining the three plant parts for B accumulation under adequate availability of this micronutrient, the stems accumulated the most $(519.5 \mu \mathrm{g} / \mathrm{plant})$, corresponding to $49 \%$ of the total amount taken up by the plants (Table 1). Under B omission, accumulations were greatest in the stems and roots, each with approximately $36 \%$ of the total absorbed amount, indicating the low mobility for redistribution of B in physic nut plants. Xu \& Wang (2011) found no effect of $B$ soil application on the fruit production of physic nut, also explaining this by the low B mobility in this species, concluding that very little of the nutrient accumulated in the older tissues is redistributed to other new parts of the plant.

Regarding the accumulation of cationic micronutrients, most $\mathrm{Fe}$ and $\mathrm{Zn}$ was accumulated in the stems of the complete treatment (Table 1), with

Table 1. Boron, $\mathrm{Cu}, \mathrm{Fe}, \mathrm{Mn}$, and $\mathrm{Zn}$ accumulation in the plant parts of physic nut, grown in complete nutrient solution and in absence of $\mathrm{B}, \mathrm{Cu}, \mathrm{Fe}, \mathrm{Mn}$, and $\mathrm{Zn}$

\begin{tabular}{|c|c|c|c|c|}
\hline Treatment & Upper leaf & Lower leaf & Stem & Root \\
\hline & \multicolumn{4}{|c|}{$\mathrm{B}$ accumulation ( $\mu \mathrm{g} / \mathrm{plant})$} \\
\hline Complete & $267.4 \mathrm{aB}$ & $153.4 \mathrm{aC}$ & $519.5 \mathrm{aA}$ & $128.7 \mathrm{aC}$ \\
\hline B omission & $76.3 \mathrm{bB}$ & $17.8 \mathrm{bC}$ & $128.7 \mathrm{bA}$ & $130.6 \mathrm{aA}$ \\
\hline \multirow[t]{2}{*}{$\mathrm{CV}(\%)$} & 15.81 & 22.76 & 19.90 & 12.51 \\
\hline & \multicolumn{4}{|c|}{$\mathrm{Cu}$ accumulation ( $\mu \mathrm{g} / \mathrm{plant})$} \\
\hline Complete & $158.8 \mathrm{aA}$ & $86.7 \mathrm{aA}$ & $158.7 \mathrm{aA}$ & $66.6 \mathrm{aA}$ \\
\hline $\mathrm{Cu}$ omission & $72.1 \mathrm{bB}$ & $34.0 \mathrm{bC}$ & $118.2 \mathrm{aA}$ & $39.2 \mathrm{bC}$ \\
\hline \multirow[t]{2}{*}{$\mathrm{CV}(\%)$} & 22.92 & 14.67 & 27.42 & 25.29 \\
\hline & \multicolumn{4}{|c|}{ Fe accumulation ( $\mu \mathrm{g} /$ plant $)$} \\
\hline Complete & $878.0 \mathrm{aC}$ & $573.6 \mathrm{aD}$ & $2105.5 \mathrm{aA}$ & $1550.3 \mathrm{aB}$ \\
\hline Fe omission & $137.9 \mathrm{bB}$ & $490.3 \mathrm{bA}$ & $339.2 \mathrm{bAB}$ & $262.4 \mathrm{bAB}$ \\
\hline \multirow[t]{2}{*}{$\mathrm{CV}(\%)$} & 20.32 & 28.31 & 9.58 & 8.15 \\
\hline & \multicolumn{4}{|c|}{ Mn accumulation ( $\mu \mathrm{g} /$ plant) } \\
\hline Complete & $458.3 \mathrm{aA}$ & $451.8 \mathrm{aA}$ & $304.8 \mathrm{aB}$ & $92.4 \mathrm{aC}$ \\
\hline Mn omission & $101.2 \mathrm{bA}$ & $103.9 \mathrm{bA}$ & $97.9 \mathrm{bA}$ & $56.3 \mathrm{bA}$ \\
\hline \multirow[t]{2}{*}{$\mathrm{CV}(\%)$} & 19.06 & 9.51 & 27.99 & 11.67 \\
\hline & \multicolumn{4}{|c|}{ Zn accumulation ( $\mu \mathrm{g} / \mathrm{plant})$} \\
\hline Complete & $651.4 \mathrm{aC}$ & $518.8 \mathrm{aC}$ & $1527.5 \mathrm{aA}$ & $1102.3 \mathrm{aB}$ \\
\hline Zn omission & $271.3 \mathrm{bB}$ & $340.5 \mathrm{bB}$ & $681.9 \mathrm{bA}$ & $238.3 \mathrm{bB}$ \\
\hline $\mathrm{CV}(\%)$ & 27.24 & 4.47 & 3.21 & 10.90 \\
\hline
\end{tabular}

Means followed by the same upper-case letter in rows and lower-case letter in columns are not significantly different by Tukey's test at $\mathrm{p}<0.05$. 
$41 \%(2,105.5 \mu \mathrm{g} / \mathrm{plant})$ and $40 \%(1,527.6 \mu \mathrm{g} / \mathrm{plant})$ respectively, of the total accumulated. According to Soares et al. (2001), arboreal species such as physic nut tend to accumulate more nutrients in the stem, in view of the significant contribution of dry matter in relation to the other parts (Figure 1).

There were no differences between the parts regarding $\mathrm{Cu}$ accumulation in the plants grown in the complete solution. In turn, Mn accumulation was greater in the leaves (recently expanded, opening and mature) of the plants of the complete treatment, corresponding to approximately $70 \%$ of the total amount taken up. Under conditions of adequate Mn supply, the micronutrient concentration is greatest in the chloroplasts (Pedas et al., 2005; Kering et al., 2009), explaining the greater accumulation of this element in the leaves under conditions of adequate supply.

There were differences in the quantities accumulated in the leaves (recently expanded, opening and mature) of the plants grown in complete solution and the treatments in absence of $\mathrm{B}, \mathrm{Cu}, \mathrm{Fe}, \mathrm{Mn}$, and $\mathrm{Zn}$ (Table 1). The leaves of plants grown in complete solution accumulated about $28 \%$ of the Fe and $31 \%$ of the total $\mathrm{Zn}$ taken up, while in the treatments in absence of these elements, the leaves accumulated 51 and $40 \%$ of the total, respectively; this indicates apparent mobility of $\mathrm{Fe}$ and $\mathrm{Zn}$ in the phloem, as pointed out by Page et al. (2006) and by Tsukamoto et al. (2009) in their experiments regarding translocation and redistribution of ${ }^{65} \mathrm{Zn}$ and ${ }^{52} \mathrm{Fe}$ isotopes. The results indicate a greater capacity to control the remobilization of $\mathrm{Fe}$ and $\mathrm{Zn}$ from the places of residence (accumulation sites in the initial plant development phases - i.e., cotyledonary roots or leaves) to the new leaves, as reported by Hocking (1994). Garnet \& Graham (2005) suggested that wheat plants have a greater capacity for redistribution of $\mathrm{Fe}$ from vegetative organs to new tissues (strong sinks) in relation to $\mathrm{Zn}$ and $\mathrm{Mn}$. However, there is no pattern of remobilization of these elements among species, and intraspecific or genotypic variation regarding redistribution of micronutrients via the phloem is also possible.

In this study, the leaves of the plants grown in complete solution accounted for approximately $52 \%$ of the total $\mathrm{Cu}$ accumulated, while for the treatment with $\mathrm{Cu}$ omission this was only $40 \%$ of the total taken up, indicating low phloem mobility of $\mathrm{Cu}$ in physic nut. A similar result was observed for the leaf concentrations of $\mathrm{Mn}$ and $\mathrm{B}$, which declined to $13 \%$ of the total Mn absorbed and $12 \%$ of the total B when the respective nutrient was omitted. However, despite the low $\mathrm{Cu}$ accumulation and phloem mobility, the level of this element was sufficient for vegetative development, reducing the dry matter production (Figure 1) and chlorophyll content only slightly (Figure 2). This result is in agreement with Chaves et al. (2009b), who reported a low $\mathrm{Cu}$ demand during initial growth of physic nut. In another study by the same group (Chaves et al., 2009a), the authors observed low $\mathrm{Cu}$ concentrations in all parts of the physic nut plants.

Therefore, this species is probably efficient in absorbing and/or using $\mathrm{Cu}$ (Cu uptake efficiency and $\mathrm{Cu}$ use efficiency), explaining the absence of $\mathrm{Cu}$ deficiency symptoms. However, for the photosynthesis rate (Figure 3 ), $\mathrm{Cu}$ omission caused a significant reduction of $58 \%$ in relation to the control treatment. The reason in that $\mathrm{Cu}$ in leaf cells is associated with plastocyanin, which participates in the flow of electrons in the light phase of photosynthesis, establishing the connection between the two

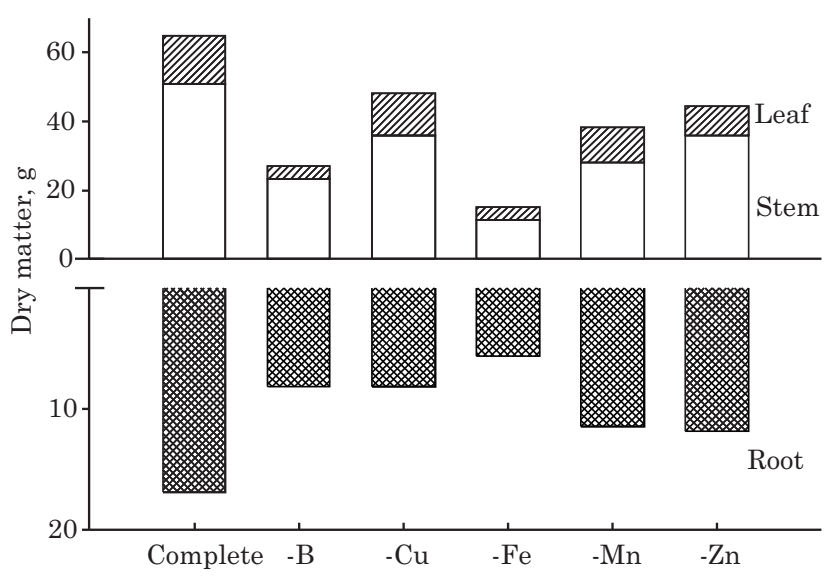

Figure 1. Dry matter yield of plant parts of physic nut, grown in complete nutrient solution and in absence of $\mathrm{B}, \mathrm{Cu}, \mathrm{Fe}, \mathrm{Mn}$, and $\mathrm{Zn}$.

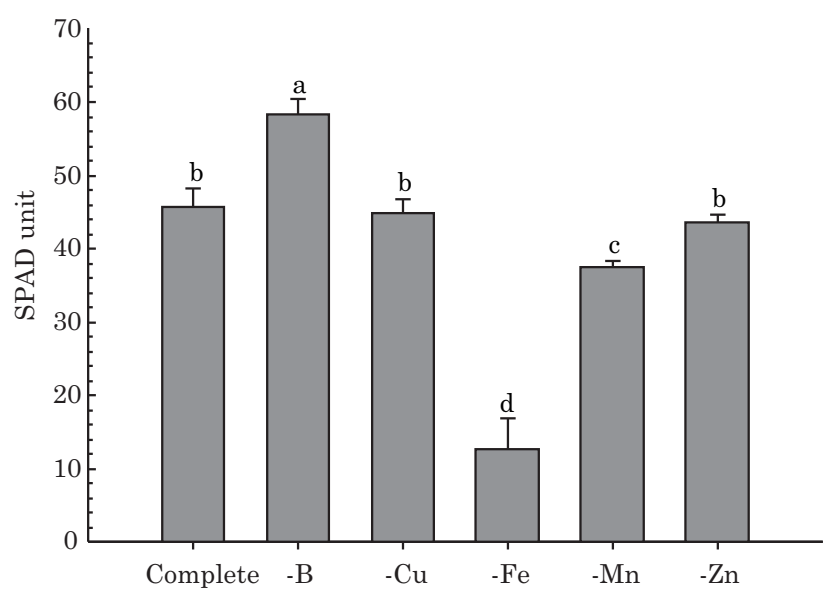

Figure 2. Chlorophyll content in SPAD units, measured in the middle lobe of the third and fourth recently expanded leaves of physic nut grown in complete nutrient solution and in absence of $\mathrm{B}, \mathrm{Cu}, \mathrm{Fe}, \mathrm{Mn}$, and $\mathrm{Zn}, 105$ days after the start of the treatments. Means followed by the same letter are not significantly different by Tukey's test at $p<0.05$. 
photosystems (PS-II and PS-I). Furthermore, $\mathrm{Cu}$ participates in the dark phase of photosynthesis by activating ribulose bisphosphate carboxylase, which is responsible for the entrance of $\mathrm{CO}_{2}$ in organic compounds.

The results of photosynthesis rates observed in plants grown without $\mathrm{Cu}$, limit the hypothesis of efficiency of $\mathrm{Cu}$ absorption and/or of its use in the initial growth phase of physic nut only. Therefore, if the experiment had lasted longer, the lower photosynthesis rate would have caused greater reductions in dry mass and appearance of $\mathrm{Cu}$ deficiency symptoms, mainly under conditions of greater nutritional demand (e.g., at flowering and fruiting).

The weekly measurements of chlorophyll content (SPAD units) in the leaves showed that in all treatments except $\mathrm{B}$ omission reduction in chlorophyll content according to the passing of time, notably in the first evaluations (Figure 4). A possible explanation for this reduction in SPAD values with time is the aging of the leaves in the complete treatment (Hellgren \& Ingestad, 1996). Also, these micronutrients are not highly mobile for redistribution in the phloem, helping to explain the lower concentrations in new tissues (Table 1) in the treatments with individual omission, as well as the limitation of the chlorophyll biosynthesis in these treatments (Figure 2).

The differences in the treatments were probably associated with the chlorophyll biosynthesis, which is influenced by the level of the micronutrients (Marschner, 1995). Among the micronutrients studied, $\mathrm{B}$ is least related to the photosynthesis process (Epstein \& Bloon, 2006), so explaining why the omission of this element interfered least with the chlorophyll

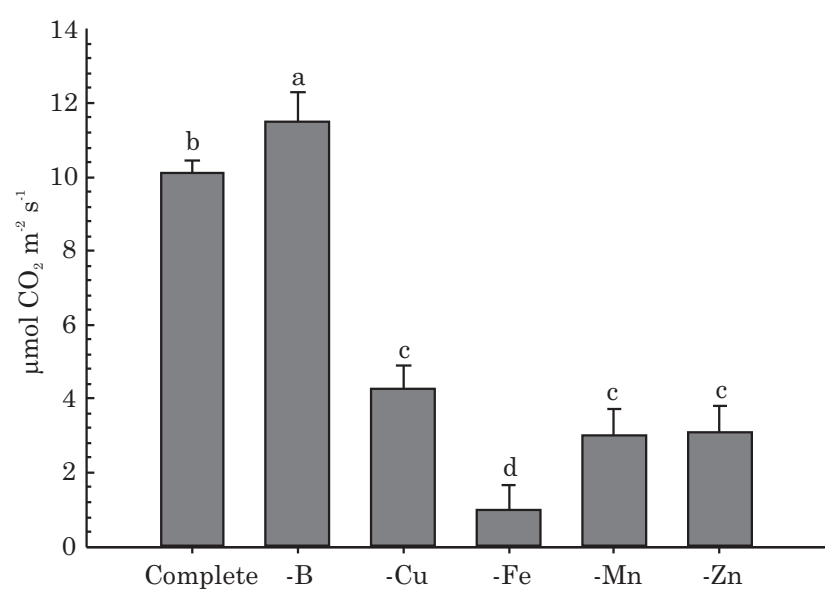

Figure 3. Photosynthesis rate measured in the middle lobe of the third and fourth recently expanded leaves of physic nut grown in complete nutrient solution and in absence of $B$, $\mathrm{Cu}, \mathrm{Fe}, \mathrm{Mn}$, and $\mathrm{Zn}, 105$ days after the start of the treatments. Means followed by the same letter are not significantly different by Tukey's test at $\mathbf{p}<0.05$. concentration (Figure 2) and photosynthesis rate (Figure 3) of physic nut.

The omission of B increased the chlorophyll level (SPAD units) by $28 \%$ (Figure 2) and the photosynthesis rate by $14 \%$ (Figure 3 ) in relation to the complete treatment. This increase in the chlorophyll content and photosynthesis rate is probably due to the smaller leaf area (smaller and narrower leaves), which was not accompanied by a decline in the chlorophyll concentration. Boron is involved in vegetative growth, tissue differentiation, synthesis of carbohydrates and metabolism of phenol compounds. It should be further noted that the functions of $B$ initially involve synthesis, lignification and formation of the cell wall structure, as well as the structural integrity of plant membranes (Hänsch \& Mendel, 2009). Since all these functions are fundamental for meristematic tissues, the deficiency of B mainly impairs organs during growth, explaining why the leaves in the treatment without B were stunted. The intense green color of the leaves observed at the end of the experiment corroborates the hypothesis of the effect on the chlorophyll content and photosynthesis rate.

In the treatment without $\mathrm{Fe}$ there was a significant reduction in the chlorophyll content up to 63 days after the start of treatment, which stabilized thereafter until the end (Figure 4). The first consequence of low $\mathrm{Fe}$ uptake is generalized chlorosis, induced by the rapid reduction in the content of photosynthetic pigments (Malavolta et al., 1997),

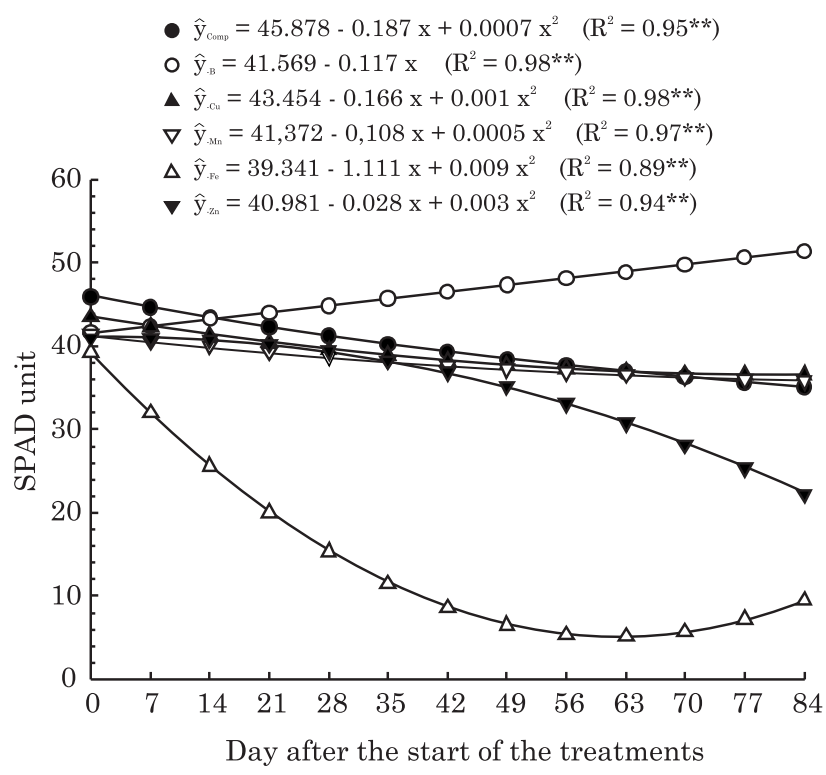

Figure 4. Chlorophyll content, in SPAD units, measured on the middle lobe of the third and fourth recently expanded leaves of physic nut grown in complete nutrient solution and in absence of $\mathrm{B}, \mathrm{Cu}, \mathrm{Fe}, \mathrm{Mn}$, and $\mathrm{Zn}$, according to the evaluation day. 
explaining the decline in the chlorophyll concentration in this study. The omission of Fe resulted in lower SPAD values in relation to the other treatments towards the end of the experiment (Figure 2), when there was a $72 \%$ reduction in the chlorophyll level in comparison with the complete treatment. The plants grown in the solution without Fe also showed the greatest declines in the photosynthesis rate, up to $90 \%$, compared to those in the control treatment. Various studies in the literature indicate that $\mathrm{Fe}$ deficiency causes rapid decrease in the levels of photosynthetic pigments and a substantial reduction in the transport of electrons in photosynthesis, since this nutrient, along with sulfur, participates in the composition of the ferredoxin molecule, which is the final acceptor of electrons in photosynthesis I (Hänsch $\&$ Mendel, 2009). Lange et al. (2005) also reported lower SPAD values in castor bean plants, of the same botanical family as physic nut, grown in a nutrient solution without Fe.

$\mathrm{Fe}$ is essential for the chlorophyll synthesis. Ferritin, which stores and releases Fe, makes up about $75 \%$ of the content of chloroplasts in leaf cells. Moreover, Fe participates in the electron transport in the process of reduction via cytochromes and ferredoxin (Marschner, 1995; Mengel \& Kirkby, 2001; Malavolta, 2006).

The omission of $\mathrm{Zn}$ did not affect the SPAD values at the end of the experiment (Figure 2). The delayed appearance of $\mathrm{Zn}$ deficiency symptoms explains this result, but $\mathrm{Zn}$ deficiency did cause a significant reduction $(69 \%)$ in the photosynthesis rate in relation to the complete treatment (Figure 3), similar to the treatment without $\mathrm{Cu}$. The reason for this decreased photosynthesis rate is that $\mathrm{Zn}$ is required at the active site of carbonic anhydrase, an enzyme responsible for fixation of atmospheric $\mathrm{CO}_{2}$. The carbonic anhydrase located in the cytoplasm and chloroplasts can facilitate carbon transfer for carbohydrate fixation and synthesis (Hänsch \& Mendel, 2009), so Zn omission impaired the activity of carbonic anhydrase and hence reduced photosynthetic activity.

Finally, the omission of $\mathrm{Mn}$ also caused a reduction in the SPAD values, of $18 \%$ (Figure 2), and of $70 \%$ in the photosynthesis rate (Figure 3 ) when compared to the complete treatment. This is explained by the fact that Mn participates in the photolysis of water (water photosynthesis or Hill's reaction), in which electrons from water are transferred to chlorophyll. The protein that catalyzes the decomposition of water is oxidized by photosynthesis II, which in turn oxidizes the water, releasing molecular oxygen (Pedas et al., 2005; Kering et al., 2009). This protein has four Mn atoms in its active center (Marschner, 1995; Mengel \& Kirkby, 2001; Malavolta, 2006). Therefore, Mn deficiency affects the structure of the chloroplasts, explaining our results. Besides, $\mathrm{Mn}$ is an activator of various enzymes of the dark phase of photosynthesis, such as phosphoenolpyruvate carboxykinase and the malic enzyme.

\section{CONCLUSIONS}

1. The omission of Fe, B and Mn limits the biomass production of physic nut the most.

2 . The chlorophyll content and photosynthesis rate are reduced by deficiencies of the micronutrients tested here, except for the absence of B.

3. The omission of $B$ has the least limiting effect on the development of physic nut in the initial growth phase.

\section{ACKNOWLEDGEMENTS}

The authors would like to acknowledge Leonardo Cirilo da Silva Soares, a doctoral student at the "Luiz de Queiroz" College of Agriculture, University of São Paulo, for his help with the equipment for evaluation of the photosynthesis rate. They are also indebted to State of São Paulo Research Foundation (FAPESP) for the masters scholarship (Ref. Proc. 2011/15208-0) given to Elcio Ferreira Santos and the scholarship (Ref. Proc. 2010/12411-7) of Raphael Florencio Garrone and to National Council for Scientific and Technological Development (CNPq) (Ref. Proc. 137912/ 2010-2) for the scholarship of Aline Grella de Campos.

\section{LITERATURE CITED}

BALOTA, E.L.; MACHINESKI, O. \& SCHERER, A. Mycorrhizal effectiveness on physic nut as influenced by phosphate fertilization levels. R. Bras. Ci. Solo, 36:23-32, 2012.

BECKMANN-CAVALCANTE, M.Z.; PIVETTA, K.F.L.; CAVALCANTE, I.H.L.; CAVALCANTE, L.F.; BELLINGIERI, P.A. \& CAMPOS, M.C.C. Condutividade elétrica da solução nutritiva para o cultivo do crisântemo em vaso. R. Bras. Ci. Solo, 34:747-756, 2010.

BEHERA, S.K.; SRIVASTAVA, P.; TRIPATHI, R.; SINGH, J.P. \& SINGH, N. Evaluation of plant performance of Jatropha curcas L. under different agro-practices for optimizing biomass - A case study. Biomass Bioener., 34:30-41, 2010.

CAKMAK, I. \& RÖMHELD, V. Boron deficiency-induced impairments of cellular functions in plants. Plant Soil, 193:71-83, 1997.

CHAVES, L.H.G.; CABRAL, P.C.; BARROS JUNIOR, G.; LACERDA, R.D. \& DANTAS JUNIOR, E.E. Zinco e cobre em pinhão manso. II. Teores dos elementos em folhas e caule. R. Caatinga, 22:100-106, 2009a.

CHAVES, L.H.G.; CUNHA, T.H.C.S.; BARROS JUNIOR, G.; LACERDA, R.D. \& DANTAS JUNIOR, E.E. Zinco e cobre em pinhão manso. I. Crescimento inicial da cultura. R. Caatinga, 22:94-99, 2009b. 
CHAVES, L.H.G.; MESQUITA, E.F.; ARAUJO, D.L. \& FRANÇA, C.P. Crescimento, distribuição e acúmulo de cobre e zinco em plantas de pinhão-manso. R. Ci. Agron., 41:167-176, 2010.

DIAS, L.A.S.; LEME, L.P.; LAVIOLA, B.G.; PALLINI FILHO, A.; PEREIRA, O.L.; CARVALHO, M.; MANFIO, C.E.; SANTOS, A.S.; SOUSA, L.C.A.; OLIVEIRA, T.S. \& DIAS, D.C.F.S. Cultivo de pinhão-manso (Jatropha curcas L.) para produção de óleo combustível. Viçosa, MG, 2007. 40p.

EPSTEIN, E. \& BLOOM, A.J. Nutrição mineral de plantas: Princípios e perspectivas. 2.ed. Sunderland, Sinauer, 2006. 400p.

GARNETT, T.P. \& GRAHAM, R.D. Distribution and remobilization of iron and copper in wheat. Ann. Bot., 95:817-826, 2005.

HÄNSCH, R. \& MENDEL, R.R. Physiological functions of mineral micronutrients $(\mathrm{Cu}, \mathrm{Zn}, \mathrm{Mn}, \mathrm{Fe}, \mathrm{Ni}, \mathrm{Mo}, \mathrm{B}, \mathrm{Cl})$. Curr. Opin. Plant Biol., 12:259-266, 2009.

HELLGREN, O. \& INGESTAD, T. A comparison between methods used to control nutrient supply. J. Exp. Bot. 47:117-122, 1996.

HOCKING, P.J. Dry matter production, mineral nutrient concentrations, and nutrient distribution and redistribution in irrigated spring wheat. J. Plant Nutr., 17:1289-1308, 1994.

KERING, M.K.; LUKASZEWSKA, K. \& BLEVINS, D.G. Manganese requirement for optimum photosynthesis and growth in NAD-malic enzyme C-4 species. Plant Soil, 316:217-226, 2009.

LANGE, A.; MARTINES, A.M.; SILVA, M.A.C.; SORREANO, M.C.M.; CABRAL, C.P. \& MALAVOLTA, E. Efeito de deficiência de micronutrientes no estado nutricional da mamoneira cultivar Iris. Pesq. Agropec. Bras., 40:61-67, 2005.

LAVIOLA, B.G. \& DIAS, L.A.S. Teor e acúmulo de nutrientes em folhas e frutos de pinhão-manso. R. Bras. Ci. Solo, 32:1969-1975, 2008.

LAVRES JUNIOR, J.; BOARETTO, R.M.; SILVA, M.L.S.; CORREIA, D.; CABRAL, C.P. \& MALAVOLTA, E. Deficiências de macronutrientes no estado nutricional da mamoneira cultivar Iris. Pesq. Agropec. Bras., 40:145$151,2005$.

LAVRES JUNIOR, J.; CABRAL, C.P.; ROSSI, M.L.; NOGUEIRA, T.A.R.; NOGUEIRA, N.L. \& MALAVOLTA, E. Deficiency symptoms and uptake of micronutrients by castor bean grown in nutrient solution. R. Bras. Ci. Solo, 36:233-242, 2012.

LIMA, R.L.S.; SEVERINO, L.S.; GHEYI, H.R.; SOFIATTI, V. \& ARRIEL, N.H.C. Efeito da adubação fosfatada sobre o crescimento e teor de macronutrientes de mudas de pinhão manso. R. Ci. Agron., 42:950-956, 2011.

MAIA, J.T.S.; GUILHERME, D.O.; PAULINO, M.A.O.; SILVEIRA, H.R.O. \& FERNANDES, L.A. Efeito da omissão de macro e micronutrientes no crescimento d pinhão-manso. R. Caatinga, 24:174-179, 2011.
MALAVOLTA, E. Manual de nutrição mineral de plantas. São Paulo, Agronômica Ceres, 2006. 631p.

MALAVOLTA, E.; VITTI, G.C. \& OLIVEIRA, S.A. Avaliação do estado nutricional das plantas: Princípios e aplicações. 2.ed. Piracicaba, Potafos, 1997. 319p.

MARSCHNER, H. Mineral nutrition of higher plants. London, Academic Press, 1995. 889p.

MENGEL. K. \& KIRKBY, E. Principles of plant nutrition. 5 th ed. Dordrecht/Boston/London, Kluwer Academic Publishers, 2001. 849p.

MINOLTA CAMERA Co. Manual for chlorophyll meter Spad502. Osaka, Minolta, Radiometric Instruments Divisions, 1989. 22p.

MOCHIDA, K. \& SHINOZAKI, K. Advances in Omics and bioinformatics tools for systems analyses of plant functions. Plant Cell Physiol., 52:2017-2038, 2011.

OPENSHAW, K. A review of Jatropha curcas: An oil plant of unfulfilled promise. Biomass Bioener., 19:1-15, 2000.

PAGE, V.; WEISSKOPF, L. \& FELLER, U. Heavy metals in white lupin: Uptake, root-to-shoot transfer and redistribution within the plant. New Phytol., 171:329$341,2006$.

PARAWIRA, W. Biodiesel production from Jatropha curcas: A review. Sci. Res. Essays, 5:1796-1808, 2010.

PEDAS, P.; HEBBERN, C.A.; SCHJOERRING, J.K.; HOLM, P.E. \& HUSTED, S. Differential capacity for highaffinity manganese uptake contributes to differences between barley genotypes in tolerance to low manganese availability. Plant Physiol., 139:1411-1420, 2005.

REIS, A.R.; FAVARIN, J.L.; MALAVOLTA, E.; LAVRES JUNIOR, J. \& MORAES, M.F. Photosynthesis, Chlorophylls, and SPAD readings in coffee leaves in relation to nitrogen supply. Commun. Soil Sci. Plant Anal., 40:1512-1528, 2009.

SAS Institute Inc. SAS/STAT. User's Guide, version 8.0. Cary, 2000.

SATURNINO, H.M.; PACHECO, D.D.; KAKIDA, J.; TOMINAGA, N. \& GONÇALVES, N.P. Cultura do pinhão-manso (Jatropha curcas L.). Inf. Agropec., 26:44-78, 2005.

SILVA, E.B.; TANURE, L.P.P.; SANTOS, S.R. \& RESENDE JÚNIOR, P.S. Sintomas visuais de deficiências nutricionais em pinhão-manso. Pesq. Agropec. Bras., 44:392-397, 2009

SILVA, E.N.; RIBEIRO, R.V.; FERREIRA-SILVA, S.L.; VIEGAS, R.A. \& SILVEIRA, J.A.G. Comparative effects of salinity and water stress on photosynthesis, water relations and growth of Jatropha curcas plants. J. Arid Environ., 74:1130-1137, 2010.

SILVA, E.N.; RIBEIRO, R.V.; SILVA, S.L.F.; VIÉGAS, R.A. \& SILVEIRA, J.A.G. Salt stress induced damages on the photosynthesis of physic nut young plants. Sci. Agric., 68:62-68, 2011. 
SOARES, C.R.F.S.; ACCIOLY, A.M.A.; MARQUES, T.C.L.L.S.M.; SIQUEIRA, J.O. \& MOREIRA, F.M.S. Acúmulo e distribuição de metais pesados nas raízes, caule e folhas de mudas de arvores em solo contaminado por rejeitos de indústria de zinco. R. Bras. Fisiol. Veg., 13:302$315,2001$.

SOUZA, P.T.; SILVA, E.B.; GRAZZIOTTI, P.H. \& FERNANDES, L.A. NPK fertilization on initial growth of physic nut seedlings in Quartzarenic Neossol. R. Bras. Ci. Solo, 35:559-566, 2011.
TSUKAMOTO, T.; NAKANISHI, H.; UCHIDA, H.; WATANABE, S.; MATSUHASHI, S.; MORI, S. \& NISHIZAWA, N.K. ${ }^{52} \mathrm{Fe}$ translocation in barley as monitored by a positron-emitting tracer imaging system (PETIS): Evidence for the direct translocation of $\mathrm{Fe}$ from roots to young leaves via phloem. Plant Cell Physiol., 50:48-57, 2009.

XU, G. \& WANG, R. Sulfur and boron-magnesium-zinc compound fertilizer contribute to the reproductive growth of Jatropha curcas L. J. Plant Nutr., 34:1843-1852, 2011. 